ECOLOGICA, Vol. 28, No 101 (2021), 112-117

https://doi.org/10.18485/ecologica.2021.28.101.17

Originalni naučni rad

UDC:616-036.21:330.34

\title{
Uticaj pandemije na ekonomski razvoj
}

\section{The impact of the pandemic on economic development}

\author{
Milan Janković ${ }^{1}$, Adriana Jović Bogdanović ${ }^{2}$, Aleksandra Gajdobranski \\ 1,2,3Fakultet za poslovne studije i pravo, Jurija Gagarina 149a, Beograd \\ 1,2,3 Faculty of Business Studies and Law, Jurija Gagarina 149a, Belgrade
}

Rad primljen: 23.01.2021, Rad prihvaćen: 23.02.2021.

Sažetak: Pandemija KOVID-19, je bez presedana u svom globalnom dosegu i uticaju, predstavljajući strašne izazove u ekonomijama sveta i njenih direktnih i indirektnih efekata u međusobno povezanoj globalnoj ekonomiji. Šireći se alarmantnom brzinom, zarazivši milione i dovevši skoro do zastoja sve ekonomske aktivnosti, zemlje su nametale stroga ograničenja kretanja da bi zaustavile širenje virusa. Kako zdravstvo i ljudski troškovi rastu, ekonomska šteta je već evidentna i predstavlja najveći ekonomski šok koji je svet doživeo decenijama. Ovaj članak se fokusira na ekonomski uticaj KOVID-19. Opisuje uticaj pandemije na globalnu ekonomiju kroz koja je povezana trgovinom i investicijama, a njeno usporavanje i ograničenja vrši pritisak stvarajući pritom svetske ekonomske posledice, osvrčući se kratko i na R.Srbiju, i kakav je uticaj na zaposlenost, globalni ekonomski rast i obim globalne trgovine kao priliv stranih direktnih investicija i kako će uticati na dalji globalni razvoj ekonomije. Ova pandemija KOVID-19 uticala je na proizvodni i uslužni sektor, ugostiteljstvo, putovanja, zdravstvo, maloprodaja, banke, hoteli, nekretnine, obrazovanje, zdravstvo, IT, rekreacija, mediji i drugi. Ekonomski stres je počeo i brzo će rasti. Dok zaključavanje i socijalno udaljavanje s jedne strane rezultiraju gubitkom produktivnosti, s druge strane uzrokuju nagli pad potražnje za proizvodima i uslugama od strane potrošača na tržištu, što dovodi do kolapsa ekonomske aktivnosti. Međutim, zaključavanje i socijalno distanciranje jedini su isplativi alati koji sprečavaju širenje KOVID-19. Postoji velika stopa nesigurnosti u vezi sa KOVID-19, čija pandemija utiče na ekonomske performanse, kriterijume održivosti i razvojne procese. Analiza njegovog rasta u zemljama jasno pokazuje da njegov razvoj dovodi do kriza. Smanjenje stopa BDP-a nanosi štetu zdravstvu, obrazovanju i industrijskom napretku na globalnom nivou. KOVID19 utiče na socio-ekonomske prilike zbog opadanja globalnog BDP-a, opadanja tokova kapitala, manje mogućnosti za investiranje i smanjenog prometa. Mnoge zemlje se bore da zaustave širenje epidemije KOVID-19, istovremeno izbegavajući dramatičan pad ekonomske aktivnosti.

Ključne reči: pandemija, KOVID-19, globalna ekonomija, ekonomski uticaj, ekonomska kriza, dugoročni efekti pandemije.

\begin{abstract}
The Covid-19 pandemic is unprecedented in its global reach and impact, presenting dire challenges in the world's economies and its direct and indirect effects in the interconnected global economy. Spreading at an alarming rate, infecting millions and bringing almost all economic activity to a standstill, countries have imposed strict restrictions on movement to stop the spread of the virus. As health and human costs rise, economic damage is already evident and represents the greatest economic shock the world has experienced in decades. This article focuses on the economic impact of Covid-19. He describes the impact of the pandemic on the global economy through which it is linked to trade and investment, and its slowdown and restrictions put pressure, creating global economic consequences, looking briefly at the Republic of Serbia, and the impact on employment, global economic
\end{abstract}

${ }^{1}$ orcid.org/0000-0001-7286-5845, e-mail: milan.jankovic@fpsp.edu.rs

${ }^{2}$ orcid.org/0000-0003-3201-5541, e-mail: adriana.jovic.bogdanovic@fpsp.edu.rs

${ }^{3}$ orcid.org/0000-0002-4978-5553, e-mail: aleksandra.gajdobranski@fpsp.edu.rs 
growth and global trade. as an inflow of foreign direct investment and how it will affect the further global development of the economy. This pandemic of COVID-19 affected the production and service sector, catering, travel, health, retail, banks, hotels, real estate, education, health, IT, recreation, media and others. Economic stress has begun and will grow rapidly. While locking and social distancing on the one hand result in a loss of productivity, on the other hand they cause a sharp drop in demand for products and services by consumers in the market, leading to a collapse in economic activity. However, locking and social distancing are the only cost-effective tools to prevent the spread of COVID-19. There is a high degree of uncertainty regarding COVID-19, whose pandemic affects economic performance, sustainability criteria, and development processes. The analysis of its growth in the countries clearly shows that its development leads to crises. Reducing GDP rates is detrimental to health, education, and industrial progress globally. COVID-19 affects socio-economic opportunities due to declining global GDP, declining capital flows, fewer investment opportunities and reduced turnover. Many countries are struggling to stop the spread of the Covid-19 epidemic, while avoiding a dramatic drop in economic activity.

Keywords: pandemic, COVID-19, global economy, economic impact, economic crisis, long-term effects of the pandemic.

\section{UVOD / INTRODUCTION}

Izbijanje pandemije KOVID-19 drastično je uticalo na ekonomiju mnogih država sveta zbog karantina, lockdown-a, zatvaranja granica i drugih vrsta blokada proizvodnih aktivnosti. Svi resursi su sada preusmereni na suočavanje sa nikada pre viđenom krizom u svim privrednim sektorima, obrazovnom sistemu, zdravstvu, transportu, turizmu, sportu (Đurović et al., 2020). Zbog uticaja pandemije došlo je do usporavanja ekonomskog I društvenog razvoja.

Pandemija izazvana širenjem oboljenja KOVID19 je u toku, što sprečava sveobuhvatno proučavanje njenog uticaja, tako da je prerano za prognoze ekonomskog razvoja u ovoj fazi. Međutim, bilo je nekoliko pokušaja da se proceni potencijalni uticaj na ekonomiju, uzimajući u obzir sve preventivne mere i ograničenja koje su preduzete u svetu.

Najveće pandemije mogu imati značajan ekonomski uticaj na pogođenu zemlju, što ilustruju slučajevi SARS-a, MERS-a i ebole. Prema nekim procenama, ako se pandemija KOVID 19 prevaziđe u roku od godinu dana pad BDP-a će iznositi oko $2,0 \%$. BDP će značajnije pasti ako postoje proširena ograničenja kretanja i obima trgovine (WTO, 2021).

Izbijanje pandemije KOVID-19 izazvano širenjem koronavirusa ima mnogo šire razmere, što ilustruje činjenicu da izbijanje zaraznih bolesti može dovesti do ozbiljnih ekonomskih poremećaja. Pandemija već utića na međunarodnu trgovinu u celini. Kao što je naglasila Svetska trgovinska organizacija: "Očekuje se da će svetska trgovina pretrpeti pad od $13 \%$ do $32 \%$ tokom 2020 . godine (WTO, 2020).

Rašireni poremećaji u proizvodnji, rastući troškovi zaliha zbog smanjene domaće potrošnje i veliki izdaci za plate i kamate, kao I drugi finansijski izdaci, uticali su i na tokove malih, mikro i srednjih preduzeća, što je dovelo do brojnih bankrota.

Sve više država preduzima brze i odlučne korake za kontrolisanje širenja virusa. U zavisnosti od vremena potrebnog za izbijanje vrhunca, uvode se mere koje mogu ublažiti kratkoročne ekonomske rizike kao na primer kampanje za podršku malim preduzećima, subvencije, odloženo plaćanje poreza, smanjenje hipotekarnih kamatnih stopa što će pomoći vraćanju poverenja na tržištu kroz veći publicitet i javni nadzor.

Produženje masovnih karantinskih mera uzrokuje recesiju u ekonomijama siromašnih zemalja, koje ne mogu da priušte tako oštre mere kao neke bogatije države. Možemo pretpostaviti da će karantini i lockdowni duže trajati zbog čega će se ekonomska kriza pogoršati. Bogate države moći će da pozajmljuju ogromne sume novca za uvođenje poreskih olakšica, ali mnoge zemlje u razvoju to neće moći.

\section{MATERIJALI I METODE / MATERIALS AND METHODS}

Pandemija izazvana virusom KOVID-19 iznenada je zahvatila svet početkom 2020 god. i za kratko vreme uspela je da dovede zdravstvene sisteme i privrede mnogih zemalja praktično do kolapsa. Prognoze o oporavku tokom 2021. u velikoj meri nisu optimistične i teško je govoriti o dugoročnijim efektima

Jedan od razloga svakako jeste taj što je sama pandemija virusa u velikoj meri i dalje nepredvidiva, budući da se još uvek ne zna dovoljno o ponašanju i mnogobrojnim mutacijama virusa. Drugi razlog jeste to što su javne finansije zemalja tokom proteklog perioda bile pod značajnim pritiskom usled povećanih izdataka na zdravstvo, istraživanja i proizvodnju novih lekova i vakcina, a takođe pomoć privredi Stoga ne treba isključivati mogućnost fiskalne kontrakcije i talasa mera štednje koje bi se takođe mogle negativno odraziti na privredni rast. $\mathrm{Da}$ bi se razumeo potencijalni negativni ekonomski uticaj pandemije, važno je razumeti ekonomske kanale prenosa kroz koje će šokovi negativno uticati na ekonomiju. 
Prvi je direktan uticaj koji je povezan sa smanjenom potrošnjom dobara i usluga. Produženo trajanje pandemije i mere socijalne izolacije mogu rezultirati zadržavanjem potrošača kod kuće, opreznih u pogledu dugoročnih ekonomskih izgleda. Drugi je indirektni uticaj koji se ispoljava zbog šokova na finansijskim tržištima i njihovih efekata na realnu ekonomiju. Bogatstvo domaćinstava će verovatno pasti, štednja će se povećati, a potrošnja će se i dalje smanjivati. Treći se sastoji od poremećaja na strani snabdevanja. Budući da KOVID-19 zaustavlja proizvodnju i distribuciju što će negativno uticati na lance snabdevanja, potražnju radne snage i zaposlenost, to će dalje dovesti do produženih perioda otpuštanja radnika i rastuće nezaposlenosti (Carlsson-Szlezak et al., 2020).

Uticaj KOVID-19 na tokove prihoda i rashoda u ekonomiji se može odraziti na domaćinstva, zbog smanjenja ili ukidanja plata, što rezultira smanjenjem potrošnje. Nedostatak bankarskih sredstava od štednje smanjuje investicije i na kraju umanjuje kapitalni dobitak. Šokovi potražnje/ponude uzrokuju poremećaje u domaćim i međunarodnim lancima snabdevanja. Svi prethodni poremećaji dovode do pada proizvodnje, što uzrokuje smanjenje proizvodnih faktora zbog smanjenog radnog vremena ili otpuštanja.

Takođe je važno razumeti procese koji generišu oporavak od ekonomskih kriza. Postoje različite metode oporavka nakon šokova kroz koncept "geometrije šoka“. Postoje tri široka scenarija ekonomskog oporavka. Najoptimističniji je onaj sa nazivom „V-oblik“, pri čemu se agregatna proizvodnja raseljava i brzo oporavlja i vraća na stanje pre krize. Takođe, postoji put u obliku slova „U“, kad se ekonomija sporo vraća na svoj put pre krize. Jaz između starog i novog izlaznog puta je velik. I najzad, u slučaju vrlo sumornog puta u obliku slova „L“, proizvodnja opada, a stope rasta nastavljaju da opadaju (Baldwin, Weder di Mauro, 2020).

Savremena ekonomija je složena mreža međusobno povezanih strana: zaposlenih, preduzeća, dobavljača, potrošača i finansijskih posrednika. Svako je nečiji zaposleni, kupac, zajmodavac itd. Zbog vrlo visokog stepena međusobne povezanosti i specijalizacije proizvodnih aktivnosti, svaki poremećaj u lancima snabdevanja i kružnim tokovima imaće kaskadni efekat. Ovakav poremećaj je uobičajen tokom ekonomske krize koju karakterišu neizvesnosti, zbog smanjenja poverenja u tržišta i ekonomske transakcije. Konačno, intenzitet šoka određuju epidemiološke osobine i širenje epidemije KOVID-19 i povezane $s$ tim promene ponašanja potrošača i kompanija u zavisnosti od mogućnosti odgovora javne politike u državi.

\section{REZULTATI I DISKUSIJA / RESULTS AND DUSCUSSION}

Pandemija je izazvala krizu javnog zdravlja, ali je uticala i na globalnu ekonomiju. Značajan ekonomski pad već se dogodio širom sveta usled smanjene produktivnosti, gubitka ljudskih života, zatvaranja preduzeća, prekida trgovine i desetkovanja turističke industrije (Vassiljeva et al., 2020).

Pandemija KOVID-19 može biti taj poziv za „buđenje“ upućen globalnim liderima da pojačaju saradnju u cilju obezbeđenja neophodnog finansiranja kolektivnih međunarodnih akcija za mere prevencije i pripravnosti za ublažavanje rizika od velikih epidemija.

Ekonomska situacija ostaje globalno vrlo fluidna za većinu zemalja i regiona. Neizvesnost oko dužine i dubine negativnih ekonomskih efekata povezanih sa zdravstvenom krizom izaziva nestabilnosti na finansijskim tržištima i teškoće u donošenju korporativnih odluka. Pored toga, nesigurnost u pogledu razvoja i dužine globalne pandemije i efikasnosti javnih politika čiji je cilj da spreče njeno širenje i naredne talase povećale su nestabilnost tržišta. U sve većem broju slučajeva, korporacije odlažu investicione odluke, otpuštaju radnike koji su prethodno bili nezamenljivi, a u nekim slučajevima objavljuju o bankrotu.

Međunarodni monetarni fond (MMF), Organizacija za ekonomsku saradnju i razvoj (OECD) i Svetska banka revidiraju svoje prognoze naniže, što odražava brzo pogoršanje stanja globalne ekonomije i osetni pad projektovane stope rasta.

Između oktobra 2019. i oktobra 2020. MMF je smanjio prognozu globalnog ekonomskog rasta sa pozitivnih $3,4 \%$ na negativnih $4,4 \%$. Slično tome, OECD je smanjio prognozu sa $2,9 \%$ u novembru 2019. na $-4,5 \%$ u septembru 2020.

OECD je u decembru 2020. godine projektovao da će biti manje negativnog pada na globalnom nivou.

Između januara 2020. i juna 2020. godine, u većini prognoza, predviđalo se da će napredne ekonomije doživeti najoštriji pad ekonomskog rasta od 2019. do sredine juna 2020. (IMF, 2021).

Međunarodna organizacija rada (ILO) procenila je da $93 \%$ radnika u svetu trpi različite vrste ograničenja na radnom mestu i da je $8,8 \%$ globalnog radnog vremena izgubljeno u odnosu na 2019 godinu, ILO je procenila da gubitak u radnom vremenu postoji za nekoliko kategorija radnika:

1) radnici koji su bili nezaposleni, ali su aktivno tražili zaposlenje,

2) radnici koji su bili zaposleni, ali im je skraćeno radno vrijeme, $\mathrm{i}$ 
3) radnici koji su bili nezaposleni i nisu aktivno tražili posao .

$\mathrm{Na}$ osnovu ovog pristupa, ILO je procenila da je nezaposlenost na globalnom nivou ekvivalentna 0,9\% ukupnog radnog vremena izgubljenog $u$ 2020. godini. Ukupan broj izgubljenih radnih sati u 2020. u poređenju sa 2019. bio je najveći u Evropi $(14,6 \%)$ i Americi $(13,7 \%)$, gde su mere karantina i blokade bile opsežne. Globalni gubici radnih mesta u 2020. godini iznosili 114 miliona radnih mesta u odnosu na 2019. Udeo izgubljenih radnih sati zbog većih stopa nezaposlenosti bio je najveći u Evropi $(6,0 \%)$, Americi $(2,7 \%)$, uključujući Sjedinjene Države i arapskim državama (1,7\%) (ILO, 2021).

Predviđa se da će se obim globalne trgovine delimično oporaviti 2021. godine povećanjem po godišnjoj stopi rasta od 7,2\% (WTO, 2021).

Ažurirana prognoza takođe ukazuje na to da bi oporavak globalne trgovine 2021. mogao biti primetno sporiji nego što je STO projektovala u aprilu, pre svega zbog sporijeg oporavka globalnog BDPa 2021. Globalni priliv stranih direktnih investicija opao je za $49 \%$ u prvoj polovini 2020. godine u poređenju sa istim periodom 2019. godine. Prilivi u razvijene ekonomije su opali za $75 \%$, dok je priliv u Evropu opao sa 203 milijarde dolara u prvoj polovini 2019. na -7 milijardi u prvoj polovini 2020 . Međunarodno finansiranje projekata razvoja infrastrukture je opalo za $25 \%$ (UNCTAD, 2020).

Učesnici na tržištu takođe su zabrinuti zbog finansijske $i$ ekonomske neizvesnosti $u$ ekonomijama u razvoju i tržištima u razvoju, jer su se mnogi od njih već suočili sa nepovoljnim situacijama. Razlog zbog kojeg se ove ekonomije suočavaju sa ozbiljnim uticajem krize je pad cena proizvoda usled šoka potražnje i ponude, poremećaji lanaca snabdevanja, pad izvoza usled recesije u naprednim zemljama i zahtev za domaćom primenom mera prevencije. Razvijene zemlje mogu ublažavati recesiju uz pomoć fiskalnih paketa, ali zemlje u razvoju nemaju fiskalnu pomoć potrebnu za upravljanje krizom.

Pandemija KOVID-19 svakako je obeležila 2020. godinu, koju će privreda U R.Srbiji pamtiti po ubrzanoj digitalnoj transformaciji i uspostavljanju lanaca vrednosti, opsežnim preventivnim merama u suzbijanju inficiranja korona virusom na radnom mestu, a takođe uvođenjem upravljanja timovima na daljinu.

Očekuje se da će kriza izazvana KOVID-19 uticati na privredu Srbije prvenstveno u sektoru prerađivačke industrije, pri čemu su od naročitog značaja izvoz i proizvodnja trajnih dobara. Proizvođači-izvoznici zapošljavaju veći broj radnika od svih sektora na koje bi kriza mogla da utiče. Moglo bi doći do negativnog efekta talasa jer tražnja za izvozom pada a logistika (npr. uvoz sirovina) postaje sve složenija. Pored toga, tražnja za trajnim dobrima često bilježi nagli pad u uslovima krize.

Kod privrednika su najprisutniji strahovi od nove-produžene krize, čak $73 \%$ firmi pribojava se narednih talasa pandemije i ponovnih zatvaranja, a takođe pada tražnje za proizvodima i uslugama. Oko $40 \%$ firmi očekuje ograničenja povezana sa padom likvidnosti poslovanja, padom dostupnih izvora finansiranja, promene u izvoznim i uvoznim politikama. Više od $90 \%$ firmi očekuje pad prihoda u ovoj godini. Neke firme su spremnije dočekale krizu, oslonjene na digitalne modele poslovanja, $30 \%$ je unapredilo postojeće kanale onlajn prodaje, dok većina smatra da su digitalna rešenja veoma važna za dalji oporavak. Oko $13 \%$ firmi je otvorilo onlajn prodavnice ili planira to da uradi, a $30 \%$ planira da digitalizuje poslovne procese, prilagodi se novonastaloj situaciji i koristi digitalni marketing kao deo strategije oporavka. Nalazi pokazuju da firme uključene u međunarodne lance snabdevanja češće planiraju promene proizvodnih procesa ili uvođenje novih proizvoda (USAID, 2021).

Mikro i mala preduzeća u Srbiji zapošljavaju najveći broj ljudi. Osim direktnog zapošljavanja, ova preduzeća imaju mnogo širi društveni uticaj na kvalitet života za preko 3 miliona ljudi u našoj zemlji - porodice zaposlenih, male dobavljače poput poljoprivrednih gazdinstava kojima je bez ovih preduzeća egzistencija ugrožena. Dodatno, veliki broj ovih preduzeća posluje u nerazvijenim opštinama gde predstavljaju važan oslonac i prihode za lokalne zajednice. Pandemija KOVID 19 postavila je pred nas, pored mnogih drugih, i ekonomski izazov - kako održati likvidnost privrede i sačuvati radna mesta, naročito u poslovanju mikro i malih preduzeća.

Rezultati istraživanja pokazuju da $85 \%$ mikro i malih preduzeća procenjuje da će pandemija imati negativan uticaj na njihovo poslovanje. Oko $80 \%$ ovih preduzeća očekuje smanjenje potražnje za svojim proizvodima i uslugama tokom i nakon trajanja pandemije, dok oko $30 \%$ mikro i malih preduzeća smatra da će se to odraziti na smanjenje broja zaposlenih u preduzećima. Preko $70 \%$ preduzeća očekuje da će osećati ekonomske posledice pandemije na poslovanje 6 meseci i duže. Finalno, preko $48 \%$ preduzeća procenjuje da ove izazove neće moći da prevaziđu bez dodatne podrške (UPS, 2020).

Uprkos činjenici da je 2021 godina neizvesna, jer sa jedne strane, tada većina naših privrednika dolazi na naplatu odloženih poreskih davanja, a 
negativni uticaj pandemije neće nestati barem $u$ prvih 6 meseci 2021 godine. Tek u poređenju sa očekivanjima od prethodne godine vidi se zapravo efekat pandemije na poslovanje i očekivanja za rast biznisa. Ukoliko uporedimo ova očekivanja sa ranijim istraživanjima, sličan nivo rasta poslovanja, je pokazatelj u očekivanju brzog oporavka nakon prestanka pandemije, a to će biti najveći izazov u 2021. godini

KOVID-19 je uticao na ekonomiju uglavnom kroz tri kanala:

- smanjenje izvoza, što odražava potisnutu globalnu ekonomsku aktivnost;

- smanjenje potražnje povezane sa ulazom, u pozadini mera i politika ograničenja ulaska koje smanjuju putovanja, i

- smanjenje domaće privatne potrošnje, što odražava obustavu poslovanja (IBRD, 2021).

Pad globalne i domaće tražnje negativno se odrazio na profit preduzeća, zarade i fiksna ulaganja u poslovanje, ali ozbiljnost uticaja je različita u zavisnosti od faktora kao što su broj obolelih od KOVID-19, struktura industrijskih sektora i prostor za fiskalni manevar.

Međutim, povećana je globalna potražnja za internetskim uslugama i za robom vezanom za IT, koja čini veliki udeo u ekonomijama širom sveta.

Efekti pandemije KOVID-19 na globalnu ekonomiju još uvek su u velikoj meri nepoznati. Zemlje širom sveta primenjuju mere zaključavanja kako bi obuzdale pandemiju KOVID-19. Vrlo brzo postaviće se pitanje kako ukinuti mere karantina, istovremeno zadržavajući epidemiju. Prva faza ovog ekonomskog odgovora na pandemiju KOVID-19 već je u toku sa merama koje su, iako skupe, relativno lagane. Druga faza, ponovno pokretanje ekonomije, uključuje izazovniji zadatak prevazilaženja strahova ljudi od zaraze virusom.

Prema podacima Univerziteta Džon Hopkins (JHU, 2021), do sredine marta 2021. godine u svetu je KOVID-19 obolelo više od 122 miliona ljudi, od kojih je 2,7 miliona umrlo. Koronavirus je otkriven davno, ali je mutirao, što je dovelo do izbijanja bolesti u današnje vreme. Izvršen je jak pritisak na ekonomije mnogih zemalja, stope uvoza i izvoza su opale, ali naučnici nastavljaju da proučavaju KOVID19. Istraživanja su takođe pokazala da je epidemija uticala na proizvodnju mnogih dobara, čak su i najveće kompanije obustavile proizvodnju svojih proizvoda. Mnogo ljudi širom sveta ostalo je nezaposleno, nekima je skraćeno radno vreme, neki su primali smanjene plate, a samo mali procenat je ostao nepromenjen. Nekonvencionalna priroda ove krize zahteva nekonvencionalne mere.

I posle završetka pandemije Kovid-19, nazire se sve manje šansi za puni angažman radnika $u$ svim sektorima ekonomije (Radić et al., 2020).

\section{ZAKLJUČAK / CONCLUSION}

Koronavirus se brzo širio širom sveta. Pandemija je izazvala ozbiljne ekonomske posledice u različitim sektorima privrede negativno utičući na globalnu trgovinu, kamatne stope, likvidnost finansijskog tržišta i stvarajući šokove potražnje i ponude. Neizvesno je kada će se ekonomije širom sveta oporaviti od globalne pandemije ili koliko će dugo trajati napori za oporavak. Naša analiza faktora ukazuje na velike i trajne negativne efekte pandemije na svetsku ekonomiju, pri čemu nijedna zemlja ne može izbeći posledice.

Trenutna pandemija podstakla je države da preispitaju svoje stavove i postupke. Sama globalizacija, koja je bila osnova globalnog ekonomskog rasta pre krize, sada se dovodi u pitanje, a neki su zagovarali potrebu za premotavanjem unazad. Međutim, bez obzira na to kako se ona može promeniti u formi ili strukturi, osnovni značaj globalizacije za svetsku ekonomiju neće se promeniti.

Kako će širenje virusa verovatno i dalje remetiti ekonomsku aktivnost i negativno uticati na proizvodnu i uslužnu industriju, posebno u razvijenim zemljama, očekuje se da će finansijska tržišta i dalje biti nestabilna. Još uvek postoji pitanje da li će ova kriza koja se razvija imati trajni strukturni uticaj na globalnu ekonomiju ili uglavnom kratkoročne finansijske i ekonomske posledice.

U oba slučaja, očigledno je da zarazne bolesti poput KOVID-19 imaju potencijal da nanesu ozbiljne ekonomske i finansijske troškove regionalnim i globalnim ekonomijama. Zbog visoke saobraćajne povezanosti, globalizacije i ekonomske međusobne povezanosti, izuzetno je teško i skupo obuzdati virus i ublažiti rizike uvoza kada se bolest počela širiti na više lokacija. Ovo opravdava međunarodno kolektivno delovanje i globalno ulaganje u razvoj i distribuciju vakcina, kao i preventivne mere, uključujući izgradnju kapaciteta u nadzoru u stvarnom vremenu i razvoj sposobnosti za traženje kontakata na nacionalnom i međunarodnom nivou. Kako epidemije novih infekcija verovatno neće nestati $u$ bliskoj budućnosti, potrebne su proaktivne međunarodne akcije ne samo za spašavanje života već i za zaštitu ekonomskog prosperiteta.

Ekonomski uticaj šokova poput pandemije obično se meri agregatnim podacima iz vremenskih serija, kao što su industrijska proizvodnja, rast BDP-a, stopa nezaposlenosti i drugi. Međutim, ovi skupovi 
podataka su dostupni samo nakon određenog kašnjenja, obično meseci ili do kraja kvartala. S druge strane, ekonomski šokovi koji nastaju usled KOVID19 javljaju se u realnom vremenu.

Ne možemo sa sigurnošću da govorimo o ekonomskom efektu virusa na različite zemlje, tokom kog trajanja će mere ublažavanja trajati na različitim tržištima, prikladnosti različitih postupaka za nadoknađivanje propuštene aktivnosti i postupka u kome će domaćinstva i preduzeća promeniti svoje aktivnosti u srednjem roku. Ekonomsko usporavanje može stvoriti nove probleme u finansijskom sistemu i ako in ima nastavlja, na kraju može rezultirati finansijskom krizom.

Gledajući globalno, mora da se prihvate promenjeni uslovi u sveobuhavtanom ekonomskom pejzažu. lako će biti zaštićene najugroženije ekonomije, biće potrebne uspešne politike koje omogućavaju kapital, rad, veštine i inovacije da se prebace na nove ciljeve kako bi se stvorilo jače ekonomsko okruženje nakon KOVID-a. Neke zemlje koje se već kreću prema ovoj vrsti dinamičnosti $\mathrm{i}$ otpornosti moraće da udvostruče svoje napore. Za druge je promena posebno kritična sada, kada je pandemija ozbiljno zategnula fiskalne pozicije i kada su drugi pokretači dugoročnog rasta oslabili.

Od izbijanja pandemije KOVID-19 krajem 2019. do sredine marta 2021. umrlo je više od 2,7 miliona ljudi, a procenjuje se da se globalna ekonomija tokom 2020. smanjila za neverovatnih 4,3 odsto. Milioni radnih mesta već su izgubljeni, a procenjuje se da će 130 miliona ljudi živeti u ekstremnom siromaštvu ako se kriza nastavi. To su mračne brojke koje odražavaju ogromne izazove i ljudske patnje izazvane ovom pandemijom. Kraj KOVID-19 još se ne nazire. $U$ mnogim zemljama broj novih slučajeva zaražavanja KOVID-19 raste alarmantnom brzinom Zbog mutacije virusa i pojave veoma opasnih novih sojeva koronavirusa: britanskog, nigerijskog, kalifornijskog i drugih postoji mnogo neizvesnosti oko toga kako će i kada pandemija prestati. Zato je teško prognozirati kraj pandemije i ponuditi pouzdane modele ekonomskog razvoja posle pandemije.

\section{LITERATURA / REFERENCES}

[1] Baldwin, R., Weder di Mauro, B. (eds.), (2020). Mitigating the COVID Economic Crisis: Act Fast and Do Whatever, It Takes. CEPR Press, London.

[2] Carlsson-Szlezak, P., Reeves, M., \& Swartz, P. (2020). What Coronavirus Could Mean for the Global Economy. Preuzeto sa https://hbr.org/2020/03/what-coronaviruscould-mean-for-the-global-economy, dana 18.02.2021
[3] Đurović, S., Perović, A., Šiljak, V., Antonijević, S., Veselinović, J., Baćevac, S. (2020). Održivost razvoja sportskog turizma kao privredne grane: uticaj COVID-19, Ecologica, 27(100), 699-706.

[4] GITM, (2020). Global Investment Trends Monitor, No. 36, October 27, 2020, preuzeto sa https://unctad.org/webflyer/global-investmenttrends-monitor-no-36, dana 17.02.2021

[5] IBRD, (2021). Global Economic Prospects. International Bank for Reconstruction and Development, $1818 \mathrm{H}$. Street, N.W. Washington, DC 20433, USA (pp.19-20).

[6] ILO, (2021). ILO Monitor: COVID-19 and the World of Work, Seventh Edition, International Labor Organization, January 15, 2021, str. 2, preuzeto sa

https://www.ilo.org/global/topics/coronavirus/i mpacts-and-responses/WCMS_767028/lang-en/index.htm, dana 15.02.2021.

[7] JHU, (2021).

https://gisanddata.maps.arcgis.com/apps/ops dashboard/index.html\#/bda7594740fd402994 23467b48e9ecf6, posećeno dana 20.03.2021

[8] Radić, V., Radić, N., Ravić, N..(2020). Uticaj pandemije korona virusa na ciljeve održivog razvoja i ekonomiju, Ecologica, 27(99), 366375.

[9] UPS, (2020). Uticaj pandemije na aktivnosti preduzeća u Srbiji: Izazovi i očekivanja, Unija poslodavaca Srbije, Beograd, 2020 (str.30-32).

[10] USAID, (2021). USAID-ov projekat saradnje za ekonomski razvoj, Godinu dana za oporavak privrede od krize, preuzeto sa https://saradnja.rs/portfolio/godinu-dana-zaoporavak-privrede-od-krize/, dana 18.02.2020

[11] Vassileva, A., Simić, M., Stevanović, M. (2020). Implications of COVID-19 for international business, Ecologica, 27(100), 589-596.

[12] World economic outlook report, prezeto sa https://www.imf.org/en/Publications/WEO

[13] WTO (2021). Trade set to plunge as COVID19 pandemic upends global economy (press release), Geneva: World Trade Organization, preuzeto sa:

https://www.wto.org/english/news_e/pres20_e /pr855_e.htm, posećeno dana 13.02.2021

[14] WTO (2021a). Trade shows signs of rebound from COVID-19, recovery still uncertain, preuzeto sa https://www.wto.org/english/news_e/pres20_e /pr862_e.htm, posećeno dana 16.02.2021. 